\title{
Potential of Frangipani (Plumeria alba) Leaves Extract as Ultra Violet Protection
}

\author{
I Gusti Ngurah Agung Windra \\ Wartana Putra* \\ Putu Eka Arimbawa \\ Ni Putu Rahayu Artini \\ Department of Pharmacy, Universitas \\ Bali Internasional, Denpasar, Bali, \\ Indonesia \\ *email: agungwindra@gmail.com \\ Keywords: \\ Frangipani \\ Plumeria alba \\ SPF \\ Sunscreen \\ UV
}

\begin{abstract}
Sunlight is the source of life and energy. Besides that, sunlight also creates skin challenges such as sunburn, pigmentation, wrinkles, dermatitis, aging, and skin cancer. Natural sunscreen protection is a popular and preferred way among various regions of the world to reduce sunlight's harmful effect. This study aimed to determine the potential of frangipani (Plumeria alba) leaves extract in some concentrations as ultraviolet protection. Plumeria alba extract contained secondary metabolites such as flavonoids, phenolics, and alkaloids that function as impeding ultraviolet radiation. This study used an experimental method consisting of four treatments and six replications. This study shows that the extract with concentration 2500; 5000; 7500; and 10000 ppm consecutively have SPF value of $6.24 ; 12.00$; 18.45; and 22.64. It can be concluded the $P$. alba leaves extract potential as ultraviolet protection.
\end{abstract}

Received: September 3rd, 2020

Accepted: October $24^{\text {th }}, 2020$

Published: November 30th, 2020 Access article under the CC-BY-SA License (http://creativecommons.org/licenses/by-sa/4.0/). DOI: https://doi.org/10.33084/bjop.v3i4.1644

\section{INTRODUCTION}

Sunscreen is a substance or material that can protect the skin against ultra violet (UV) radiation's harmful effects by absorbing, diffusing, or reflecting the rays, reducing the energy that affects the skin (Eff et al., 2018; Latha et al., 2013). Cosmetic preparation that contains sunscreen is usually labeled with a specific Sun Protection Factor (SPF) strength. The SPF value is in 2-60 range, this figure shows how long the product can protect or block UV ray that causes sunburn, pigmentation, wrinkles, dermatitis, and skin cancer (Geoffrey et al., 2019; Ngoc et al., 2019; Surdu et al., 2013). In general, sunscreens with an SPF 15 value are used to protect the skin from the adverse effects of UVA and UVB (Paul, 2019). A user can determine the duration of effectiveness only by multiplying the SPF number by the length of time it takes to burn his skin when not wearing sunscreen (Wacker \& Holick, 2013).
Sunscreen cosmetic preparations on the market come in various forms such as creams, lotions, ointments, gels, or sprays applied to the skin (Perugini et al., 2019). The ingredients of this sunscreen are varied, ranging from synthetic to natural ingredients. Recently, people prefer to use natural sunscreens. This is because the natural ingredients have a less negative impact (Mishra et al., 2011). Natural sunscreen ingredients often added to sunscreens cosmetic products, e.g., carrot, soy, avocado, aloe vera, walnut, citrus fruits, lemon, marigold, sesame seeds, jojoba, and other extracts (Korać \& Khambholka, 2011; Geoffrey et al., 2019; Shanbhag et al., 2019).

Frangipani (Plumeria alba) plants are a relatively abundant plant in Indonesia, especially in Bali. This plant, originating from America, is straightforward to find in Bali, where almost every Balinese household has this plant because it is easy to grow, and it is rich in benefits. 
To grow this plant, people only need to cut the branching of the stem and stick it into the soil or fertile land, and without the need for over care, this plant will thrive. These plants have many benefits, ranging from being used as herbal medicines with various properties such as treating swelling, diarrhea, tinea versicolor, toothache, and consuming such as making vegetables (Wrasiati et al., 2011; Ningsih et al., 2014). The Balinese Hindu community uses many flowers from this plant for prayer ceremonies.

Plumeria alba offers many benefits, but the use of its leaves for sunscreen is still unknown. Various studies on P. alba leaves show that these leaves contain secondary metabolites such as flavonoids, alkaloids, phenolic compounds (Gupta et al., 2016). These secondary metabolites are compound capable of absorbing UV rays because it has a conjugated aromatic benzene group (Panche et al., 2016). Therefore, this study aimed to determine $P$. alba leaves' potential as a sunscreen by calculating the SPF value.

\section{MATERIALS AND METHODS}

\section{Materials}

The materials used include $70 \%$ ethanol, distilled water, P. alba leaves, methanol, Dragendorff's reagent, $\mathrm{FeCl}_{3}$ reagent, and $20 \% \mathrm{NaOH}$. The tools used were vacuum rotary evaporator, desiccators, maceration chamber, Erlenmeyer flasks, analytical scales, micropipette, and UV-Vis spectrophotometer.

\section{Sample sources and determination}

Plumeria alba leaves were collected from Tibubeneng village, Badung Bali, in March 2020. Plant determination is carried out by the Eka Karya Botanical Garden Conservation Center, Indonesian Institute of Sciences with specimen number B154-2 to ensure that the sample used is $P$. alba from the Apocynaceae family.

\section{Sample preparation}

The samples were green $P$. alba leaves $15-30 \mathrm{~cm}$ long. Samples were washed with flowing water and cut into small pieces. Then the samples were drained and dried by using an oven at $45^{\circ} \mathrm{C}$ for 24 hours. The samples were blended until achieving a certain degree of smoothness, and afterward, it was sieved by using an 80 mesh siever to obtain the P. alba leaves powder (Ersalina et al., 2020).

\section{Sample extraction}

Plumeria alba leaves powder weighed for $750 \mathrm{~g}$ was dissolved with ethanol solvents (materials : ethanol ratio $=1: 7 \mathrm{~b} / \mathrm{v})$. Extraction of the sample was filtered with fine filter paper. The filtrate obtained was evaporated using a rotary vacuum evaporator at $40^{\circ} \mathrm{C}$ and $40 \mathrm{rpm}$ until extract was obtained in the paste form (Ersalina et al., 2020).

\section{Qualitative test of flavonoids compounds}

As much as $2 \mathrm{~mL}$ of extract was added with $1 \mathrm{~mL}$ of $2 \mathrm{~N}$ $\mathrm{NaOH}$. The presence of yellow color indicates the presence of flavonoids (Altemimi et al., 2017).

\section{Qualitative test of alkaloids compounds}

As much as $1 \mathrm{~mL}$ of extract was stirred with $5 \mathrm{~mL}$ of $1 \%$ aqueous $\mathrm{HCl}$. Then a few drops of Dragendorff's reagent were added. The presence of green color or white precipitate indicates alkaloids' presence (Altemimi et al., 2017).

\section{Qualitative test of phenolic compounds}

As much as $0.05 \mathrm{~g}$ of the P. alba extract was put in the test tube, then mixed with $2 \mathrm{~mL}$ ethanol. The mixture was then added with two drops of $5 \% \mathrm{FeCl}_{3}$. Positive reactions were indicated by black-green or blue color (Altemimi et al., 2017).

\section{Determination of SPF value}

The P. alba extract sample was weighed at $0.1 \mathrm{~g}$ and was dissolved in $10 \mathrm{~mL}$ ethanol p.a. Sample testing was conducted by measuring its absorbance using a 
spectrophotometer at $\lambda 290-320 \mathrm{~nm}$ with a measurement interval of $5 \mathrm{~mm}$. The SPF value was performed by using a constant set (Fonseca \& Rafaela, 2013). The sample SPF value is calculated using the formula below (Cefali et al., 2019; Donglikar \& Deore, 2016):

$$
S P F=C F \times \sum_{290}^{320} E E(\lambda) \times I(\lambda) \times \mathrm{A}(\lambda)
$$

CF: Correction Factor; EE: Erythemal Effect; I: Spectrum of solar intensity at wavelength ( $\lambda$ ); Abs: Absorbance of sunscreen products at wavelength

\section{RESULTS AND DISCUSSION}

\section{Preliminary phytochemical screening}

Preliminary phytochemical screening was conducted to determine secondary metabolites content in $P$. alba extract. The test results can be seen in Table I, where $P$. alba extract is positive for flavonoids, alkaloids, and phenolics. This is in line with research conducted by (Gupta et al., 2016), where the P. alba extract tested also contained these secondary metabolites.

Table I. Qualitative phytochemical screening in $P$. alba extract

\begin{tabular}{llc}
\hline \multicolumn{1}{c}{ Reagent } & \multicolumn{1}{c}{ Phytochemical } & Results \\
\hline $\mathrm{NaOH}$ & Flavonoids & + \\
Dragendorff's & Alkaloids & + \\
$\mathrm{FeCl}_{3}$ & Phenolics & + \\
\hline
\end{tabular}

$(+)$ : presence of phytochemicals

\section{SPF value}

The SPF values of the $P$. alba extract obtained are presented in Table II. The sunscreen ability is categorized as classified by Wasitaatmadja (1997). From Table II, P. alba extract with 2500 ppm concentration can potentially be a sunscreen with an extra protection category. Plumeria alba extract with a concentration of 10000 ppm can potentially be a sunscreen with an ultra-protection category (Damogalad et al., 2013). Plumeria alba leaves extract has an SPF value due to its flavonoids, alkaloids, and phenolic contained in the extract. Phenol compounds have conjugated double bonds in the benzene ring. If it is exposed to UV light, the resonance will occur in the form of electron transfer. Flavonoids and alkaloids have UV protective properties because of the presence of a chromophore group, which is considered as a conjugated aromatic system having the ability to absorb light rays in the UV wavelength range in both UV A and B (Becker et al., 2013; Costa et al., 2015; Laeliocattleya, 2019). The SPF value is then used to construct the regression curve, as shown in Figure $\mathbf{1 .}$ From Figure 1, a regression equation that serves to predict the resulting SPF value with a specific concentration can be obtained. The higher the concentration extract used, the higher the SPF value would be.

\begin{tabular}{ccc} 
Table II. & SPF value in $P$. alba extract & \\
\hline Extract concentration $(\mathbf{p p m})$ & SPF value & Protection category \\
\hline 2500 & $6.24 \pm 0.55$ & Extra \\
5000 & $12.00 \pm 0.88$ & Maximum \\
7500 & $18.45 \pm 0.18$ & Ultra \\
10.000 & $22.64 \pm 0.18$ & Ultra
\end{tabular}

*Classification based on Wasitaatmadja (1997)

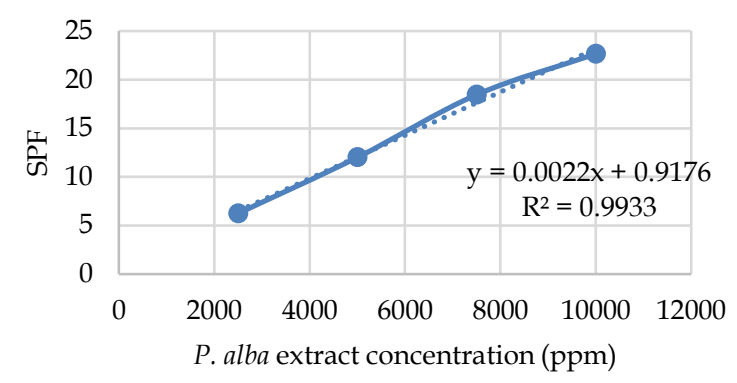

Figure 1. Regression curve of the SPF value of $P$. alba extract

Although at high concentrations $P$. alba extract can be categorized as ultra-protection, when compared to other plant extracts, the $P$. alba extract's SPF value tends to be relatively low. For example, research on SPF from the ethanol extract of Curcuma mangga reported by Yulianti et al. (2015) showed anSPF value of 35.12 from the extract at a concentration of 5000 ppm. Another study by Widyastuti et al. (2016) reported that the ethanol extract of Fragaria ananassa leaves at a concentration of 200 ppm showed an SPF value of 26.121. From the results of phytochemical screening in both studies, C. mangga and 
F. ananassa extracts also contain the same secondary metabolites shown by $P$. alba, such as flavonoids, alkaloids, and phenolics that can act as sunscreens. The difference in the SPF value obtained is thought to be due to the quantitative difference in each secondary metabolite's amount of content.

\section{CONCLUSION}

From the research results, it can be concluded that $P$. alba leaves extract has less potential as UV protection with an SPF value of 22.64 at 10000 ppm with ultra-protection category. For further research activities, it is necessary to test the phytochemical content of $P$. alba extract quantitatively and also to test the SPF value of this extract with the sunscreen base preparation.

\section{ACKNOWLEDGMENT}

This project is fully supported by the 2020 Universitas Bali Internasional Internal Research Grant.

\section{REFERENCES}

Altemimi, A., Lakhssassi, N., Baharlouei, A., Watson, D.G., \& Lighfoot, D.A. (2017). Phytochemicals: Extraction, Isolation, and Identification of Bioactive Compounds from Plant Extracts. Plants, 6(4), 42. doi:10.3390/plants6040042

Becker, C., Kläring, H.P., Kroh, L.W., \& Krumbein, A. (2013). Temporary reduction of radiation does not permanently reduce flavonoid glycosides and phenolic acids in red lettuce. Plant Physiology and Biochemistry, 72, 154-160. doi:10.1016/j.plaphy.2013.05.006

Cefali, L.C., Ataide, J.A., Fernandes, A.R., Sanchez-Lopez, E., Sousa, I.M.O., Figueiredo, M.C., Ruiz, A.L.T.G., Foglio, M.A., Mazzola, P.G., \&Souto, E.B. (2019). Evaluation of In Vitro Solar Protection Factor (SPF), Antioxidant Activity, and Cell Viability of Mixed Vegetable Extracts from Dirmophandra mollis Benth, Ginkgo biloba L., Ruta graveolens L., and Vitis vinífera L. Plants, 8(11), 453. doi:10.3390/plants8110453
Costa, S.C.C., Detoni, C.B., Branco, C.R.C., Botura, M.B., \& Branco, A. (2015). In vitro photoprotective effects of Marcetia taxifolia ethanolic extract and its potential for sunscreen formulations. Revista Brasileira de Farmacognosia, 25(4), 413418. doi:10.1016/j.bjp.2015.07.013

Damogalad, V., Edy, H.J., \& Supriati, H.S. (2013). Formulasi Krim Tabir Surya Ekstrak Kulit Nanas (Ananas comosus L MERR) dan Uji In Vitro Nilai Sun Protecting Factor (SPF). Pharmacon, 2(2), 39-43. doi:10.35799/pha.2.2013.1577

Donglikar, M.M. \& Deore, S.L. (2016). Sunscreens: A review. Pharmacognosy Journals, 8(3), 171-179. doi:10.5530/pj.2016.3.1

Eff, A.R.Y., Pertiwi, R.D., Rakhmawati, I., \& Utami, T.P. (2018). In-vitro and in-vivo Sunscreen Activity of Active Compounds Isolated from Fruits of Phaleria marcocarpha (Scheff.) Boerl. Journal of Young Pharmacists, 10(2s), S106-S110. doi:10.5530/jyp.2018.2s.21

Ersalina, E.B., Abdillah, A.A., \& Sulmartiwi, L. (2020). Potential of Caulerpa racemosa extracts as sunscreen creams. IOP Conference Series: Earth and Environmental Science, 441, 012007. doi:10.1088/1755-1315/441/1/012007

Fonseca, A.P. \& Rafaela, N. (2013). Determination of Sun Protection Factor by UV-Vis Spectrophotometry. Health Care: Current Reviews, 1(1), 1-14. doi:10.4172/23754273.1000108

Geoffrey, K., Mwangi, A.N., \& Maru, S.M. (2019). Sunscreen products: Rationale for use, formulation development and regulatory considerations. Saudi Pharmaceutical Journal, 27(7), 1009-1018. doi:10.1016/j.jsps.2019.08.003

Gupta, M., Rakhi, N.Y., Saroj, P.S., Priyanka, A.R., \& Ankit, S. (2016). Phytochemical screening of leaves of Plumeria alba and Plumeria acuminate. Journal of Chemical and Pharmaceutical Research, 8(5), 354-358.

Korać, R.R. \& Khambholja, K.M. (2011). Potential of herbs in skin protection from ultraviolet radiation. Pharmacognosy Review, 5(10), 164-173. doi:10.4103/0973-7847.91114

Laeliocattleya, R.A. (2019). The potential of methanol and ethyl acetate extracts of corn silk (Zea mays L.) 
as sunscreen. AIP Conference Proceedings, 2099, 020012. doi:10.1063/1.5098417

Latha, M.S., Martis, J., Shobha, V., Shinde, R.S., Bangera, S., Krishnankutty, B., Bellary, S., Varughese, S., Rao, P., \& Kumar, B.R.N. (2013). Sunscreening Agents: A Review. Journal of Clinical and Aesthetic Dermatology, 6(1), 16-26.

Mishra, A.K., Mishra, A., \& Chattopadhyay, P. (2011). Herbal Cosmeceuticals for Photoprotection from Ultraviolet B Radiation: A Review. Tropical Journal of Pharmaceutical Research, 10(3), 351-360. doi:10.4314/tipr.v10i3.7

Ngoc, L.T.N., Tran, V.V., Moon, J.Y., Chae, M., Park, D., \& Lee, Y.C. (2019). Recent Trends of Sunscreen Cosmetic: An Update Review. Cosmetics, 6(4), 64. doi:10.3390/cosmetics6040064

Ningsih, D.R., Zusfahair, \& Purwati. (2014). Potensi Ekstrak Daun Kamboja (Plumeria alba L.) sebagai Antibakteri dan Identifikasi Golongan Senyawa Bioaktifnya. Molekul, 9(2), 101-109. doi:10.20884/1.jm.2014.9.2.156

Panche, A.N., Diwan, A.D., \& Chandra, S.R. (2016). Flavonoids: an overview. Journal of Nutritional Science, 5, e47. doi:10.1017/jns.2016.41

Paul, S.P. (2019). Ensuring the Safety of Sunscreens, and Their Efficacy in Preventing Skin Cancers: Challenges and Controversies for Clinicians, Formulators, and Regulators. Frontiers in Medicine, 6, 195. doi:10.3389/fmed.2019.00195

Perugini, P., Bonetti, M., Cozzi, A.C., \& Colombo, G.L. (2019). Topical Sunscreen Application Preventing Skin Cancer: Systematic Review. $\begin{array}{lll}\text { Cosmetics, } & 6(3), & 42 .\end{array}$ doi:10.3390/cosmetics6030042

Shanbhag, S., Nayak, A., Narayan, R., \& Nayak, U.Y. (2019). Anti-aging and Sunscreens: Paradigm Shift in Cosmetics. Advanced Pharmaceutical Bulletin, 9(3), 348-359. doi:10.15171/apb.2019.042

Surdu, S., Fitzgerald, E.F., Bloom, M.S., Boscoe, F.P., Carpenter, D.O., Haase, R.F., Gurzau, E., Rudnai, P., Koppova, K., Févotte, J., Leonardi, G., Vahter, M., Goessler, W., Kumar, R., \& Fletcher, T. (2013). Occupational exposure to ultraviolet radiation and risk of nonmelanoma skin cancer in a multinational
European study. PLoS One, 8(4), e62359. doi:10.1371/journal.pone.0062359

Wacker, M. \& Holick, M.F. (2013). Sunlight and Vitamin D: A global perspective for health. DermatoEndocrinology, 51 51 , 108 . doi:10.4161/derm.24494

Wasitaatmadja, S.M. (1997). Penuntun Ilmu Kosmetik Medik. Jakarta, Indonesia: Universitas Indonesia.

Widyastuti, W., Kusuma, A.E., Nurlaili, N., \& Sukmawati, F. (2016). Aktivitas Antioksidan dan Tabir Surya Ekstrak Etanol Daun Stroberi (Fragaria $\mathrm{x}$ ananassa A.N. Duchesne). JSFK (Jurnal Sains Farmasi \& Klinis), 3(1), 19-24. doi:10.29208/jsfk.2016.3.1.92

Wrasiati, L.P., Hartati, A., \& Yuarini, D.A.Y. (2011). Kandungan Senyawa Bioaktif Dan Karakteristik Sensoris Ekstrak Simplisia Bunga Kamboja (Plumeria Sp.). Jurnal Biologi Udayana, 15(2), 39-43.

Yulianti, E., Adelsa, A., \& Putri, A. (2015). Penentuan nilai SPF (Sun Protection Factor) Ekstrak Etanol 70 $\%$ Temu Mangga (Curcuma mangga) dan Krim Ekstrak Etanol 70 \% Temu Mangga (Curcuma mangga) secara In Vitro Menggunakan Metode Spektrofotometri. Majalah Kesehatan, 2(1), 41-50. 